\title{
Estimation of Evapotranspiration and Crop Coefficient of Rain-Fed Tea Plants under a Subtropical Climate
}

\author{
Shenghong Zheng ${ }^{1,2,3}$, Kang $\mathrm{Ni}^{1}{ }^{1}$, Lingfei Ji ${ }^{1}$, Chenguang Zhao ${ }^{1}$, Hongling Chai ${ }^{4}$, Xiaoyun Yi ${ }^{1}$, Weizhong He ${ }^{3}$ \\ and Jianyun Ruan $1,5, *$ (D)
}

1 Key Laboratory of Tea Biology and Resource Utilization of Tea (Ministry of Agriculture), Tea Research Institute, Chinese Academy of Agriculture Sciences, Hangzhou 310008, China; zheng19851021@163.com (S.Z.); nikang@caas.cn (K.N.); 2018203023@njau.edu.cn (L.J.); zhaocg2021018@163.com (C.Z.); yixiaoyun@tricaas.com (X.Y.)

2 Graduate School of Chinese Academy of Agriculture Sciences, Beijing 100081, China

3 Lishui Academy of Agricultural and Forestry Sciences, Lishui 323000, China; lscys9949@163.com

4 Lishui Vocational and Technical College, Lishui 323000, China; chaihl2021@163.com

5 Xihu National Agricultural Experimental Station for Soil Quality, Hangzhou 310008, China

* Correspondence: jruan@tricaas.com; Tel./Fax: +86-571-8665-3938

Citation: Zheng, S.; Ni, K.; Ji, L.; Zhao, C.; Chai, H.; Yi, X.; He, W.;

Ruan, J. Estimation of

Evapotranspiration and Crop Coefficient of Rain-Fed Tea Plants under a Subtropical Climate. Agronomy 2021, 11, 2332. https:// doi.org/10.3390/agronomy11112332

Academic Editor: Martine Dorais

Received: 12 October 2021

Accepted: 16 November 2021

Published: 18 November 2021

Publisher's Note: MDPI stays neutral with regard to jurisdictional claims in published maps and institutional affiliations.

Copyright: (c) 2021 by the authors. Licensee MDPI, Basel, Switzerland. This article is an open access article distributed under the terms and conditions of the Creative Commons Attribution (CC BY) license (https:/ / creativecommons.org/licenses/by/ $4.0 /)$.

\begin{abstract}
Crop coefficient $\left(\mathrm{K}_{\mathrm{c}}\right)$ is one of the most significant parameters for crop water demand prediction and irrigation scheduling. However, there is a lack of knowledge about water vapor and $\mathrm{K}_{\mathrm{c}}$ in tea plantation ecosystems. This study explored and determined the actual evapotranspiration $\left(\mathrm{ET}_{\mathrm{C}}\right)$ and $\mathrm{K}_{\mathrm{c}}$ of two cultivars of tea (Camellia sinensis), clone variety Baiye1 (BY1) and Longjing43 (LJ43), based on lysimeter data. An estimation was made for both for $\mathrm{ET}_{\mathrm{C}}$ and adjusted $\mathrm{ET}_{\mathrm{C}}$, and the corresponding $\mathrm{K}_{\mathrm{c}}$ and adjusted $\mathrm{K}_{\mathrm{c}}$. The results showed that the adjusted $\mathrm{ET}_{\mathrm{c}}$ and $\mathrm{K}_{\mathrm{c}}$ values revealed a minor fluctuation when compared to the $\mathrm{ET}_{\mathrm{c}}$ and $\mathrm{K}_{\mathrm{c}}$ values during the experimental period, which indicated that the adjusted $\mathrm{ET}_{\mathrm{C}}$ and $\mathrm{K}_{\mathrm{c}}$ values were more precise and practical to field conditions. The average adjusted $K_{c}$ values were 0.71 (range of 0.43-1.02) for BY1 and 0.84 (range of 0.48-1.22) for LJ43. Additionally, heavy pruning can decrease $\mathrm{ET}_{\mathrm{C}}$ and $\mathrm{K}_{\mathrm{C}}$ values, possibly due to the lower level of LAI after pruning. Moreover, it is clearly manifested that BY1 consistently had lower $\mathrm{ET}_{\mathrm{C}}$ and $\mathrm{K}_{\mathrm{c}}$ values than those of LJ43 because of plant growth status differences between BY1 and LJ43. Overall, our study proposed a reliable reference of $\mathrm{K}_{\mathrm{c}}$ in tea plantation, and illuminated the effects of pruning and plant growth differences on $\mathrm{K}_{\mathrm{c}}$, which could provide a strong basis for precise irrigation in tea plantations in a subtropical climate.
\end{abstract}

Keywords: water vapor; crop coefficient; tea plantation; subtropical region; lysimeter method

\section{Introduction}

As a perennial evergreen plant originated from Southwestern China, tea plants (Camellia sinensis) favor a warm and humid climate [1]. However, to meet the water demand of tea tree growth, the temporal distribution of rainfall over the year is more vital [2-4]. Droughts usually cause irreparable yield losses, as well as prematurely aged tea plants [5-9], while heavy rainfall, on the other hand, can cause water logging, runoff, topsoil erosion, and deep percolation of critical soil nutrients [10]. In subtropical regions of China, where most tea plants are cultivated, the monthly rainfall always unevenly distributes, with frequent droughts in autumn and excessive rainfall in summer [11]. Therefore, irrigation, as a countermeasure to the droughts, is of great importance to tea plant growth.

It is necessary to schedule a proper irrigation regime according to the water demand of tea plants. Crop water demand is related to its real evapotranspiration $\left(\mathrm{ET}_{\mathrm{c}}\right)$, which combines water loss from the ground surface (evaporation) and plants (transpiration) with the atmosphere in the shape of vapor [12]. The accurate determination of $\mathrm{ET}_{\mathrm{c}}$ and 
crop coefficient $\left(\mathrm{K}_{\mathrm{c}}\right)$ is doubtlessly a benefit for assessing the water requirement of tea. It could help tea producers to decide on the optimal time and water amount of irrigation. This is of great significance for attaining the growers' purposes. In addition, the accurate determination of $\mathrm{ET}_{\mathrm{C}}$ and $\mathrm{K}_{\mathrm{c}}$ depends on the local conditions, and can increase tea yields, water use efficiency, and profits, or reduce energy use, costs, and negative environmental influences [13]. Considering the fact that the majority of Chinese tea plantations are situated in mountain areas, where tea plants can only receive either rainwater or irrigated rainwater, much attention needs to be paid to the determination of $\mathrm{ET}_{\mathrm{C}}$ and $\mathrm{K}_{\mathrm{c}}$ in the rain-fed tea plants, so as to improve the water use efficiency of the limited or uneven rainwater resource.

In practice, the crop $\mathrm{ET}_{\mathrm{C}}$ could be estimated as the proportion of the reference evapotranspiration $\left(\mathrm{ET}_{0}\right)$, which is always calculated from the Penman-Monteith equation. $\mathrm{K}_{\mathrm{c}}$ is defined as the ratio of $\mathrm{ET}_{\mathrm{c}}$ to $\mathrm{ET}_{0}[14,15]$. The $\mathrm{K}_{\mathrm{c}}$ of tea plants, recommended by the FAO paper, is from 0.9 to 1.0 [14]. However, the $\mathrm{K}_{\mathrm{c}}$ is prone to being affected by climate, crop growth, and the reference method $[16,17]$. In situ and fast frequency measurement techniques are always used in the determination of water flux, e.g., Bowen ratio-energy balance method [18], static chamber/infrared gas analyzer [19], and eddy covariance technique [20]. With the advent of new satellite technology, remote sensing approaches, together with various surface energy balance algorithms, are also employed to estimate the $\mathrm{ET}_{\mathrm{c}}$ and $\mathrm{K}_{\mathrm{c}}$ from landscapes and regions [21-24]. However, the above-mentioned methods lack accuracy, although they exhibit high temporal resolution and are suitable for annual cereal crops. Alternatively, the direct water balance method, i.e., lysimeter method, could obtain a more accurate result $[4,25,26]$. However, there was no $K_{c}$ of the tea obtained through the lysimetric data reported in China, even though China is the largest tea production country in the world. Furthermore, the effect of tea pruning practice on $\mathrm{K}_{\mathrm{c}}$ is still an open question, since periodical pruning has been reported to alter the model of energy sharing in tea plantations [27].

In this study, an attempt was made to estimate the $\mathrm{ET}_{\mathrm{c}}$ and $\mathrm{K}_{\mathrm{c}}$ of tea plantations in a subtropical region, based on in situ annual lysimeter monitoring. The objectives of this study were as follows: (1) to estimate the crop coefficient of tea (Camellia sinensis) through the water balance equation, based on a field lysimeter study; (2) to check the effect of tea cultivars and tea pruning practice on the crop coefficient of tea.

\section{Materials and Methods}

\subsection{Study Site}

The field experiment was conducted at Shengzhou Experimental Station of Tea Research Institute $\left(29.74^{\circ} \mathrm{N}, 120.82^{\circ} \mathrm{E}, 23 \mathrm{~m}\right.$ above sea level), affiliated with Chinese Academy of Agricultural Sciences (TRI-CAAS), Shaoxing, China. The experimental site was in a typical subtropical region, with average annual rainfall of $1200 \mathrm{~mm}$ and an average annual temperature of $12.6^{\circ} \mathrm{C}$, which is favorable for tea plant growth. Soil properties before the experiment are shown in Table 1.

Table 1. Soil properties before the experiment.

\begin{tabular}{|c|c|c|c|c|c|c|}
\hline \multirow{2}{*}{ Depth (cm) } & \multicolumn{3}{|c|}{ Particle Size Distribution (\%) } & \multirow{2}{*}{$\mathrm{pH}$} & \multirow{2}{*}{$\begin{array}{c}\text { Organic C } \\
\left(\mathrm{mg} \mathrm{g}^{-1}\right)\end{array}$} & \multirow{2}{*}{$\begin{array}{l}\text { Bulk Density } \\
\quad\left(\mathrm{g} \mathrm{cm}^{-3}\right)\end{array}$} \\
\hline & Sand & Silt & Clay & & & \\
\hline $0-20$ & 1.07 & 28.94 & 69.99 & 4.47 & 5.71 & 1.17 \\
\hline $20-40$ & 1.91 & 31.06 & 67.03 & 4.66 & 5.47 & 1.12 \\
\hline $40-60$ & 2.58 & 30.99 & 66.43 & 4.40 & 4.09 & 1.13 \\
\hline $60-80$ & 3.14 & 34.32 & 62.53 & 4.37 & 5.02 & 1.19 \\
\hline $80-100$ & 1.46 & 32.82 & 65.73 & 4.34 & 4.77 & 1.16 \\
\hline
\end{tabular}

Seedlings (1 year) were transplanted in the studied field in November 2015. The tea cultivars were clone variety Baiye1 (BY1) and Longjing43 (LJ43) (Figure S1a), respectively. The tea trees were planted in rows with $1.5 \mathrm{~m}$ between rows and $0.33 \mathrm{~m}$ between plants at a density of approximately 20,000 plants per hectare. Each variety was replicated in 
9 rectangular plots $\left(36 \mathrm{~m}^{2}\right.$ in area) (Figure S1b,c). After spring tea harvest, tea pruning was uniformly conducted in May 2019 and 2020 at a height that was $45 \mathrm{~cm}$ above the ground.

\subsection{Sampling and Measurement}

The 18 lysimeters ( 2 varieties and 9 replicated plots) were installed in July 2015 before the tea transplantation. Each lysimeter was $1.5 \mathrm{~m}$ in length, $1.0 \mathrm{~m}$ in width and $1.0 \mathrm{~m}$ in depth, respectively, and installed in the middle of the row with 3 tea plants in the covered area. The sketches of the installation of the lysimeter and collection of the leachate are shown in Figure S2a,b.

The leachate below $1.0 \mathrm{~m}$ was collected in the $50 \mathrm{~L}$ nylon tank below the lysimeter. In case of side seepage of soil solution, each lysimeter was surrounded by a piece of 5-mm-thick plastic film (high-density polyethylene, HDPE). Each lysimeter had two $1.5 \mathrm{~m}$ pipes, one of which was for air flow and the other one was to pump out the leachate in the 50 L nylon tank. The leachate was pumped out after the rainfall events by a mechanical vacuum pump at $25-30 \mathrm{kPa}$ (PHDmate Co., Ltd, Suzhou, China). The leachate volume was determined gravimetrically and subsamples were collected for further analysis.

An automatic weather station (SP200, LSI Lastem, Milano, Italy) located $100 \mathrm{~m}$ away from the plots provided the weather parameters, e.g., temperature, humidity, rainfall, wind and solar radiation. In addition, three tube access probes (JZSX Corp., Beijing, China) based on time domain reflectometry [28] were elaborately installed in the field to measure soil volumetric water content at $20 \mathrm{~cm}$ depth intervals until $1 \mathrm{~m}$ depth (Figure S2c).

Soil particle size was tested in pastes of $1: 5(w / v)$ in $0.2 \mathrm{M}$ sodium hydroxide solution with Mastersizer 3000 Laser particle size analyzer (Malvern Ltd., Worcestershire, UK). Soil $\mathrm{pH}$ was measured in pastes of 1:2.5 $(w / v)$ in deionized water with an ORION 3 STAR pH meter (ThermoFisher Ltd., Swedesboro, NJ, USA). Soil bulk density was determined by excavation method by dividing the mass of soil excavated by the volume of water needed to fill the hole [29]. Soil organic carbon determination was conducted via spectrophotometric absorption measurement after organic matter oxidation with potassium dichromate in concentrated sulfuric acid [30].

\subsection{Calculations and Statistical Analysis}

With the obtained daily weather parameters, reference evapotranspiration $\left(\mathrm{ET}_{0}\right)$ was calculated according to FAO-56 Penman-Monteith equation. Using the daily weather, the calculation of $\mathrm{ET}_{0}$ can be simplified as follows [14]:

$$
\mathrm{ET}_{0}=\frac{0.408 \Delta\left(\mathrm{R}_{\mathrm{n}}-\mathrm{G}\right)+\mathrm{r} \frac{900}{\mathrm{~T}+273} \mathrm{u}_{2}\left(\mathrm{e}_{\mathrm{s}}-\mathrm{e}_{\mathrm{a}}\right)}{\Delta+\mathrm{r}\left(1+0.34 \mathrm{u}_{2}\right)}
$$

where $\mathrm{ET}_{0}$ is the reference evapotranspiration $\left(\mathrm{mm} \mathrm{day}^{-1}\right), \mathrm{R}_{\mathrm{n}}$ is the net radiation at the crop surface ( $\mathrm{MJ} \mathrm{m}^{-2}$ day $\left.^{-1}\right), \mathrm{G}$ is the soil heat flux density $\left(\mathrm{MJ} \mathrm{m} \mathrm{m}^{-2}\right.$ day $\left.^{-1}\right), \mathrm{T}$ is the mean daily air temperature at $2 \mathrm{~m}$ height $\left({ }^{\circ} \mathrm{C}\right), \mathrm{u}_{2}$ is the wind speed at $2 \mathrm{~m}$ height $\left(\mathrm{m} \mathrm{s}^{-1}\right), \mathrm{e}_{\mathrm{s}}$ is the saturation vapor pressure $(\mathrm{kPa}), \mathrm{e}_{\mathrm{a}}$ is the actual vapor pressure $(\mathrm{kPa}),\left(\mathrm{e}_{\mathrm{s}}-\mathrm{e}_{\mathrm{a}}\right)$ is the saturation vapor pressure deficit $(\mathrm{kPa}), \Delta$ is the slope vapor pressure curve $\left(\mathrm{kPa}{ }^{\circ} \mathrm{C}^{-1}\right), \gamma$ psychrometric constant $\left(\mathrm{kPa}^{\circ} \mathrm{C}^{-1}\right)$, and 900 is the conversion factor.

The water balance method considered rainfall and irrigation as the primary water inputs, and subtracted the stored water content at the root zone and deep percolated water below the root zone to calculate $\mathrm{ET}_{\mathrm{C}}[31,32]$. As rainfall was the only water input in this study, the daily $\mathrm{ET}_{\mathrm{C}}$ was estimated by the following equation [33]:

$$
\mathrm{ET}_{\mathrm{c}}=\left(\mathrm{P}-\mathrm{D} \pm \sum_{\mathrm{i}=1}^{\mathrm{n}}\left(\theta_{1}-\theta_{2}\right) \Delta \mathrm{S}_{\mathrm{i}}\right) \frac{1}{\Delta \mathrm{t}}
$$

where $\mathrm{P}$ is the rainfall $(\mathrm{mm}), \mathrm{D}$ is the deep percolation $(\mathrm{mm}), \mathrm{n}$ is the number of soil layers, $\Delta S$ is the thickness of each soil layer $(\mathrm{mm}), \theta_{1}$ and $\theta_{2}$ are the volumetric soil water content 
at times one and two, respectively $\left(\mathrm{m}^{3} \mathrm{~m}^{-3}\right)$, and $\Delta \mathrm{t}$ is the time interval between two consecutive sampling times (days).

$\mathrm{K}_{\mathrm{c}}$ was computed using the estimated $\mathrm{ET}_{\mathrm{c}}$ derived from water balance equation divided by $\mathrm{ET}_{0}$ calculated via Penman-Monteith method through the following equation:

$$
\mathrm{K}_{\mathrm{c}}=\frac{\mathrm{ET}_{\mathrm{c}}}{\mathrm{ET}_{0}}
$$

where $\mathrm{ET}_{\mathrm{c}}$ and $\mathrm{ET}_{0}$ are crop evapotranspiration and reference crop evapotranspiration at different sampling intervals in this study, respectively.

F test using one-way ANOVA tested the effect of the tea variety on the tea bush structure, in terms of plant height, plant width, leaf thickness and leaf area index (LAI), and the significance of the means were calculated using Duncan's multiple range tests at significance level of 0.05 [34]. To ascertain the statistical relationship between rainfall and drainage, we used the results of cumulative rainfall and drainage at every single sampling interval. The linear plus platform model was applied to analyze the relationship between rainfall and drainage. The model can be expressed by the following equations:

$$
\begin{gathered}
y=b x+a_{1}, x<C \\
y=a_{2}, x \geq C
\end{gathered}
$$

where $a_{1}, a_{2}$ and $b$ are the parameters, and $C$ is the critical value for rainfall.

Data processing and plotting were performed using SPSS22 (SPSS Inc., New York, NY, USA) and Sigmaplot12.5 (Systat Software Inc., Milpitas, CA, USA).

\section{Results}

\subsection{Reference Evapotranspiration ( $E T_{0}$ )}

The daily $\mathrm{ET}_{0}$, together with the primary meteorological variables, including relative humidity, daily rainfall, wind speed, and air temperature during the measurement period from June 2018 to October 2020, are presented in Figure 1. The air temperature appeared to be relatively low in winter, particularly in December and January, with a mean value of $7.16^{\circ} \mathrm{C}$; whereas, the air temperature in summer was high, with the highest mean value of $28.53{ }^{\circ} \mathrm{C}$ during July to August. Similarly, the daily $\mathrm{ET}_{0}$ showed low values in winter, with a mean value of $0.80 \sim 0.96 \mathrm{~mm}^{-1 a y}{ }^{-1}$, while it reached the peak during summer, with a mean value of $4.84 \mathrm{~mm} \mathrm{day}^{-1}$ in August, during the three years.

\subsection{Precipitation and Drainage}

The time series of the cumulative rainfall and drainage distribution during the study period are illustrated in Figure 2. From June to December 2018, the total rainfall amount was $604 \mathrm{~mm}, 87 \%$ of which was in July to September. The total annual rainfall amount in 2019 was $1565 \mathrm{~mm}, 42 \%$ of which was evenly distributed during February to June, but more frequent and extreme rainfall events happened during July to December. During January to September 2020, the total rainfall was $1985 \mathrm{~mm}, 73 \%$ of which was in the period of May to September.

During the 28 months of the field experiment, there were 39 leachate collection events in total. In the period of 2018, the total leachates were $144 \mathrm{~mm}$ and $128 \mathrm{~mm}$ for BY1 and LJ43, respectively. Due to the longer measurement period in 2019, the annual total leachate was $252 \mathrm{~mm}$ for BY1 and $261 \mathrm{~mm}$ for LJ43. However, it decreased to $241 \mathrm{~mm}$ and $250 \mathrm{~mm}$ in 2020, for BY1 and LJ43, respectively.

In this study, it was found that there was an inflection point in the relationship between the cumulative rainfall and the collected leachate amount (Figure 3). It showed that the collected leachate amount remained at $20.63 \mathrm{~mm}$ and $21.45 \mathrm{~mm}$ when the cumulative rainfall increased to $78.02 \mathrm{~mm}$ and $90.98 \mathrm{~mm}$, for BY1 and LJ43, respectively, despite the increasing cumulative rainfall. 


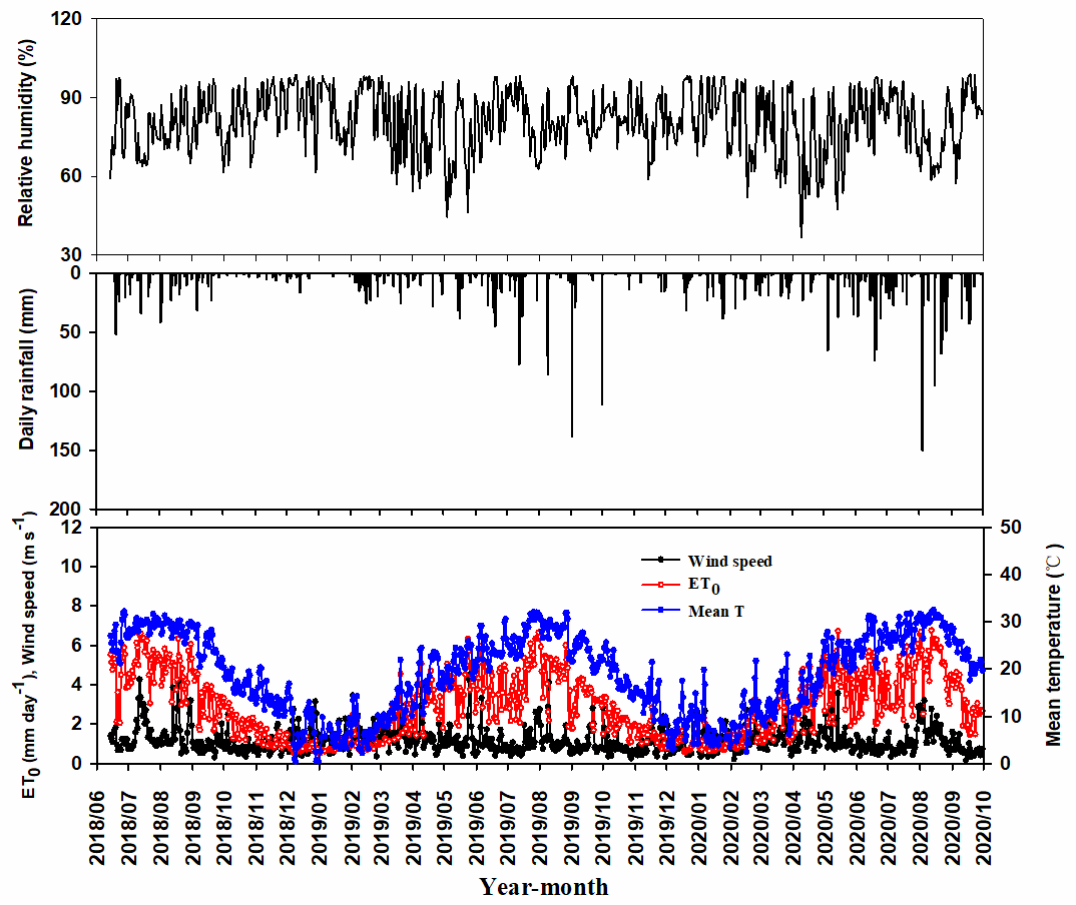

Figure 1. Daily relative humidity, rainfall, wind speed, mean air temperature and reference evapotranspiration $\left(\mathrm{ET}_{0}\right)$ during the experiment period from June 2018 to October 2020 on the research site.

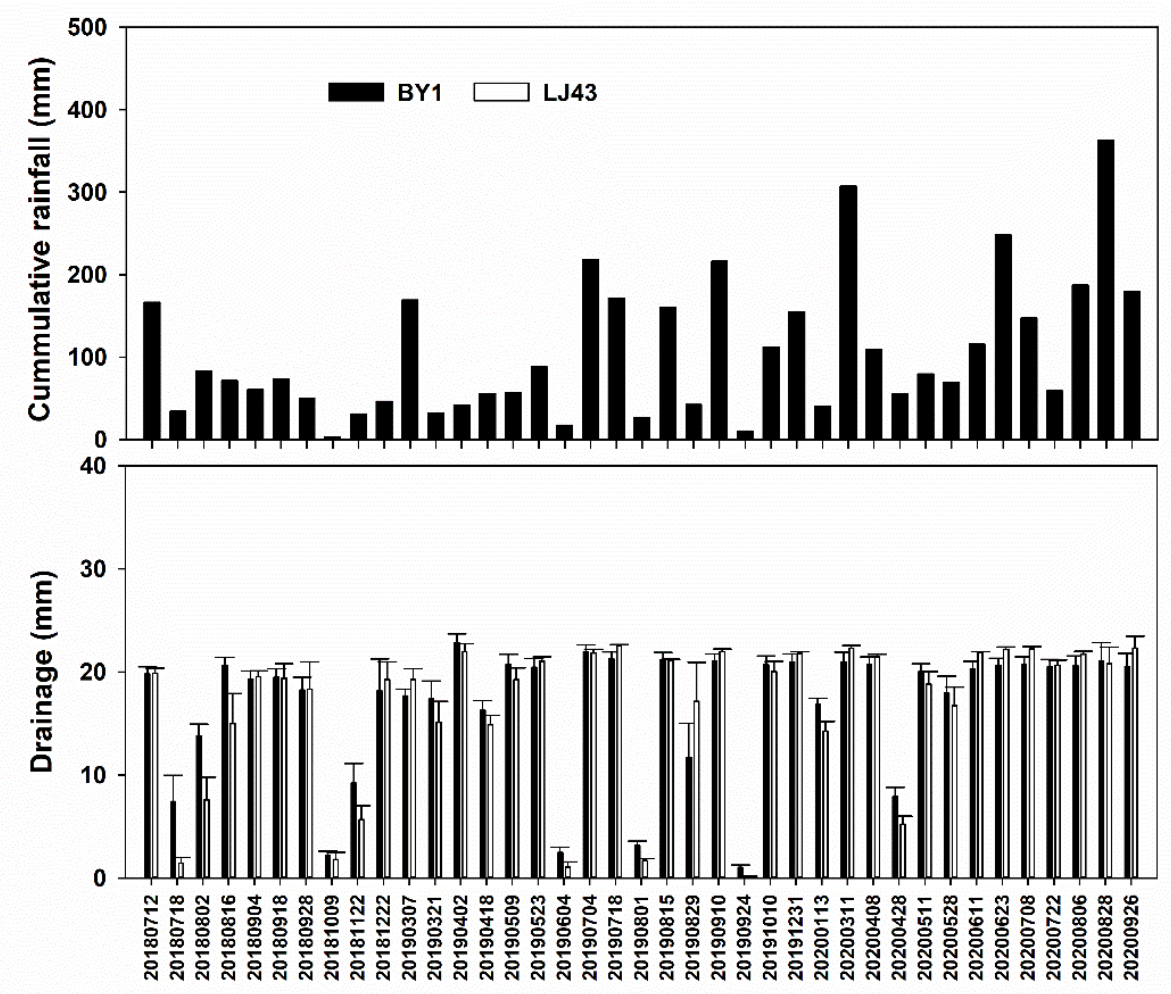

Sampling date

Figure 2. Cumulative rainfall and drainage distribution during the study period from June 2018 to September 2020. Drainage entries represent the mean values in different $\mathrm{N}$ treatments. These values are mean for all 9 barrels. Inserted error bars denote standard error of the mean. 


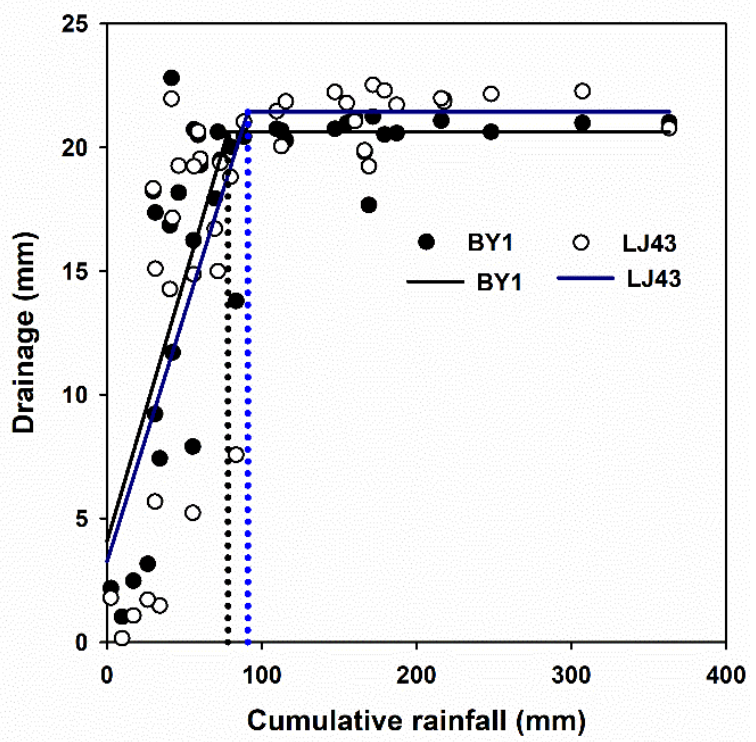

Figure 3. Correlation and change point between rainfall and drainage.

\subsection{Changes of $E T_{c}$ and $K_{c}$ during the Experiment Period}

The trends of the average $\mathrm{ET}_{\mathrm{c}}$ and adjusted $\mathrm{ET}_{\mathrm{c}}$ (calculated using critical rainfall as the water input item when the cumulative rainfall increased to and above the critical value) during the period from March 2019 to September 2020 are illustrated in Figure 4. The adjusted $\mathrm{ET}_{\mathrm{C}}$ values of BY1 and LJ43 revealed a minor fluctuation when compared to the $\mathrm{ET}_{\mathrm{C}}$ during the period of this experiment. Moreover, for both BY1 and LJ43, the summer season always exhibited a higher daily $\mathrm{ET}_{\mathrm{C}}$ and adjusted $\mathrm{ET}_{\mathrm{C}}$, while the winter season revealed the reverse result. For BY1, the maximum $\mathrm{ET}_{\mathrm{c}}$ value was $17.63 \mathrm{~mm}$ day $^{-1}$, while the maximum adjusted $\mathrm{ET}_{\mathrm{C}}$ value was $4.83 \mathrm{~mm} \mathrm{day}^{-1}$, and the minimum $\mathrm{ET}_{\mathrm{C}}$ value was $0.56 \mathrm{~mm} \mathrm{day}^{-1}$, whereas the minimum adjusted $\mathrm{ET}_{\mathrm{C}}$ value was $0.52 \mathrm{~mm} \mathrm{day}^{-1}$. For LJ43, the maximum $\mathrm{ET}_{\mathrm{C}}$ value was $17.50 \mathrm{~mm}$ day ${ }^{-1}$, whereas the maximum adjusted $\mathrm{ET}_{\mathrm{c}}$ value was $4.71 \mathrm{~mm} \mathrm{day}^{-1}$, and the minimum $\mathrm{ET}_{\mathrm{c}}$ value was $0.76 \mathrm{~mm}$ day ${ }^{-1}$, while the minimum adjusted $\mathrm{ET}_{\mathrm{c}}$ value was $0.75 \mathrm{~mm}_{\text {day }}{ }^{-1}$.

Regarding the $\mathrm{K}_{\mathrm{c}}$ value and adjusted $\mathrm{K}_{\mathrm{c}}$ value (ratio of adjusted $\mathrm{ET}_{\mathrm{c}}$ to $\mathrm{ET}_{0}$ ), for both BY1 and LJ43, the adjusted $K_{c}$ value had tiny fluctuations, while the $K_{c}$ value waved sharply during the whole experiment period (Figure 5). The $\mathrm{K}_{\mathrm{c}}$ values of BY1 and LJ43 ranged from 0.52 to 4.41 (mean $=1.61$ ) and from 0.55 to 4.39 (mean $=1.62)$, respectively, whereas the adjusted $\mathrm{K}_{\mathrm{c}}$ values of BY1 and LJ43 ranged from 0.43 to $1.02($ mean $=0.71)$ and from 0.48 to 1.22 (mean $=0.84$ ), respectively. Unlike the $\mathrm{ET}_{\mathrm{C}}$ value and adjusted $\mathrm{ET}_{\mathrm{C}}$ value, the maximum $\mathrm{K}_{\mathrm{c}}$ values of BY1 and LJ43 were present in the autumn season (September 2019), while the maximum adjusted $K_{c}$ values of BY1 and LJ43 appeared in about summer time (June 2020).

\subsection{Monthly Variation in $E T_{0}, E T_{c}$ and Adjusted $K_{c}$}

According to the sampling date and interval, each sampling date was separated to calculate the monthly $\mathrm{ET}_{0}, \mathrm{ET}_{\mathrm{c}}$, and adjusted $\mathrm{K}_{\mathrm{c}}$ values (Table 2). The values of $\mathrm{ET}_{0}$ increased from $2.35 \mathrm{~mm} \mathrm{day}^{-1}$ in March 2019 to its maximum value of $4.72 \mathrm{~mm} \mathrm{day}^{-1}$ in August 2019, and then decreased to its minimum value of $0.99 \mathrm{~mm}^{-1 a y}{ }^{-1}$ in January 2020. A similar change in monthly $\mathrm{ET}_{0}$ was found in 2020. 


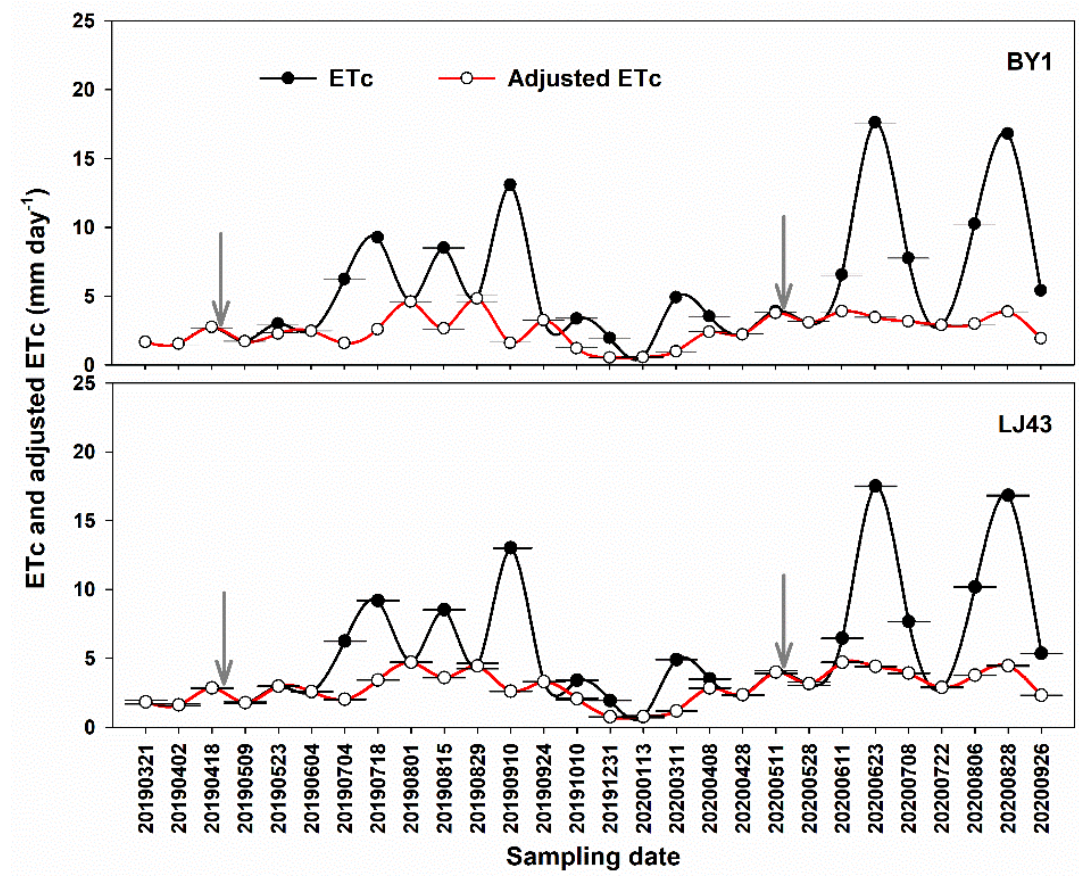

Figure 4. Variations in crop evapotranspiration $\left(\mathrm{ET}_{\mathrm{C}}\right)$ and adjusted $\mathrm{ET}_{\mathrm{C}}$ for BY1 and LJ43 during the period from March 2019 to September 2020. These values are mean of 9 lysimeters. Inserted error bars denote standard error of the mean. Vertical gray arrows denote tea pruning practice.

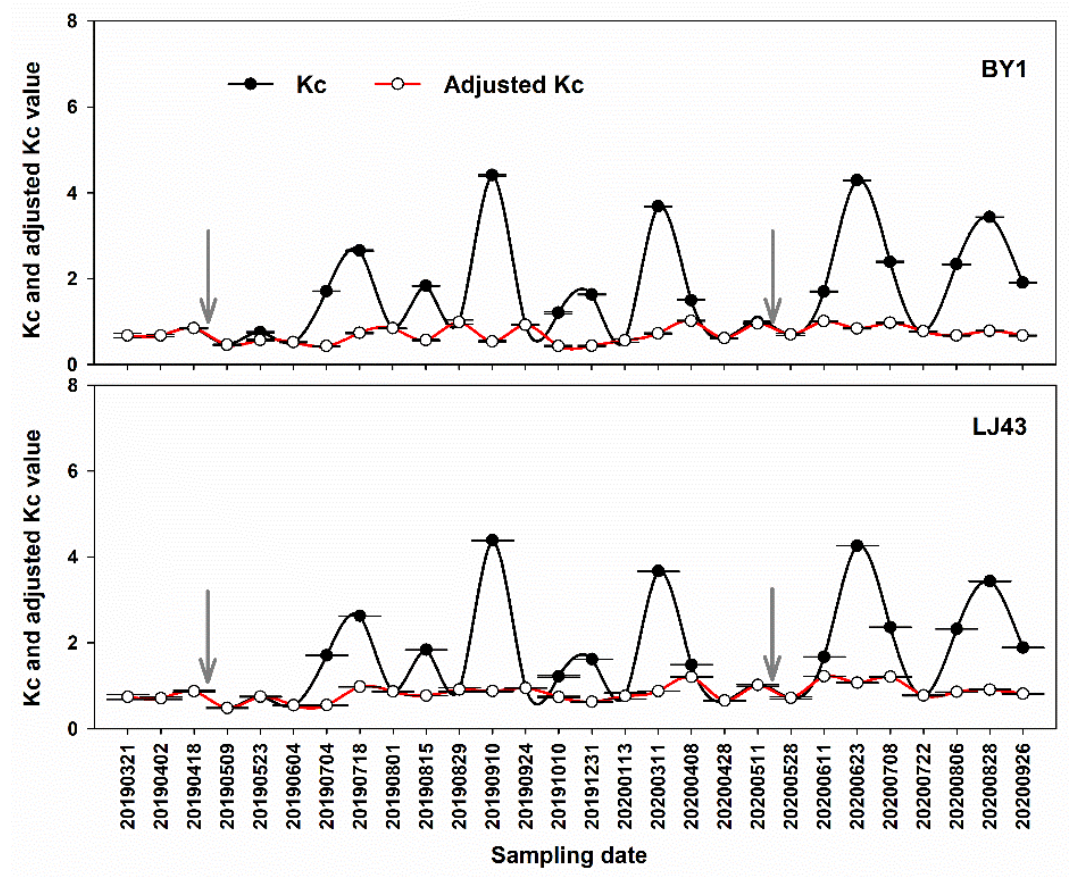

Figure 5. Variations in crop coefficient $\left(\mathrm{K}_{\mathrm{c}}\right)$ and adjusted $\mathrm{K}_{\mathrm{c}}$ for BY1 and LJ43 during the period from March 2019 to September 2020. These values are mean of 9 lysimeter barrels. Inserted error bars denote standard error of the mean. Vertical gray arrows denote tea pruning practice. 
Table 2. Monthly reference evapotranspiration $\mathrm{ET}_{0}$, crop evapotranspiration $\mathrm{ET}_{\mathrm{C}}$ and adjusted crop coefficient $\mathrm{K}_{\mathrm{c}}$ both for BY1 and LJ43 during the period from March 2019 to September 2020. Data are means and standard errors for 9 lysimeter barrels.

\begin{tabular}{|c|c|c|c|c|c|}
\hline \multirow{2}{*}{ Months } & \multirow{2}{*}{$\mathrm{ET}_{0}\left(\mathrm{~mm} \mathrm{Day}{ }^{-1}\right)$} & \multicolumn{2}{|c|}{$\mathrm{ET}_{\mathrm{c}}\left(\mathrm{mm} \mathrm{Day}{ }^{-1}\right)$} & \multicolumn{2}{|c|}{ Adjusted $K_{c}$} \\
\hline & & BY1 & LJ43 & BY1 & LJ43 \\
\hline March 2019 & $2.35 \pm 0.02$ & $1.59 \pm 0.07$ & $1.71 \pm 0.08$ & $0.68 \pm 0.03$ & $0.73 \pm 0.03$ \\
\hline April 2019 & $3.47 \pm 0.05$ & $2.23 \pm 0.14$ & $2.30 \pm 0.13$ & $0.65 \pm 0.05$ & $0.68 \pm 0.05$ \\
\hline May 2019 & $4.35 \pm 0.09$ & $2.36 \pm 0.04$ & $2.77 \pm 0.05$ & $0.54 \pm 0.01$ & $0.64 \pm 0.02$ \\
\hline June 2019 & $3.66 \pm 0.00$ & $1.58 \pm 0.02$ & $2.01 \pm 0.01$ & $0.43 \pm 0.01$ & $0.55 \pm 0.00$ \\
\hline July 2019 & $4.46 \pm 0.23$ & $3.59 \pm 0.26$ & $4.06 \pm 0.16$ & $0.79 \pm 0.02$ & $0.92 \pm 0.01$ \\
\hline August 2019 & $4.72 \pm 0.03$ & $3.66 \pm 0.31$ & $3.89 \pm 0.14$ & $0.77 \pm 0.06$ & $0.82 \pm 0.03$ \\
\hline September 2019 & $3.23 \pm 0.06$ & $2.42 \pm 0.21$ & $2.95 \pm 0.09$ & $0.73 \pm 0.05$ & $0.91 \pm 0.01$ \\
\hline October 2019 & $2.78 \pm 0.00$ & $1.20 \pm 0.05$ & $2.05 \pm 0.06$ & $0.43 \pm 0.02$ & $0.74 \pm 0.02$ \\
\hline November/December 2019 & $1.19 \pm 0.00$ & $0.52 \pm 0.01$ & $0.75 \pm 0.00$ & $0.44 \pm 0.01$ & $0.63 \pm 0.00$ \\
\hline January 2020 & $0.99 \pm 0.00$ & $0.56 \pm 0.05$ & $0.76 \pm 0.07$ & $0.56 \pm 0.05$ & $0.76 \pm 0.07$ \\
\hline Feburary/March 2020 & $1.34 \pm 0.00$ & $0.97 \pm 0.02$ & $1.17 \pm 0.00$ & $0.72 \pm 0.01$ & $0.87 \pm 0.00$ \\
\hline April 2020 & $2.96 \pm 0.15$ & $2.30 \pm 0.04$ & $2.59 \pm 0.06$ & $0.82 \pm 0.05$ & $0.93 \pm 0.07$ \\
\hline May 2020 & $4.16 \pm 0.05$ & $3.42 \pm 0.10$ & $3.57 \pm 0.12$ & $0.83 \pm 0.04$ & $0.87 \pm 0.04$ \\
\hline June 2020 & $3.98 \pm 0.03$ & $3.67 \pm 0.07$ & $4.55 \pm 0.04$ & $0.92 \pm 0.02$ & $1.15 \pm 0.02$ \\
\hline July 2020 & $3.46 \pm 0.06$ & $3.02 \pm 0.05$ & $3.43 \pm 0.13$ & $0.87 \pm 0.03$ & $1.00 \pm 0.05$ \\
\hline August 2020 & $4.64 \pm 0.06$ & $3.42 \pm 0.12$ & $4.11 \pm 0.09$ & $0.73 \pm 0.02$ & $0.88 \pm 0.01$ \\
\hline September 2020 & $2.84 \pm 0.00$ & $1.92 \pm 0.03$ & $2.31 \pm 0.01$ & $0.68 \pm 0.01$ & $0.81 \pm 0.00$ \\
\hline Monthly total & $1033.63 \pm 18.94$ & $701.60 \pm 29.67$ & $830.24 \pm 26.76$ & $0.68 \pm 0.037$ & $0.82 \pm 0.036$ \\
\hline Monthly mean & $3.21 \pm 0.29$ & $2.26 \pm 0.26$ & $2.65 \pm 0.29$ & $0.68 \pm 0.04$ & $0.82 \pm 0.04$ \\
\hline
\end{tabular}

For both BY1 and LJ43, the high $\mathrm{ET}_{\mathrm{C}}$ values often occurred in summer time, especially in July and August, both for BY1 and LJ43, while the low $\mathrm{ET}_{\mathrm{C}}$ values often appeared in winter time. The maximum and minimum values of monthly $\mathrm{ET}_{\mathrm{c}}$ were $3.67 \mathrm{~mm} \mathrm{day}^{-1}$ and $0.52 \mathrm{~mm} \mathrm{day}^{-1}$ for BY1, and $4.55 \mathrm{~mm} \mathrm{day}^{-1}$ and $0.75 \mathrm{~mm} \mathrm{day}^{-1}$ for LJ43, respectively.

The ranges of monthly adjusted $K_{c}$ values were $0.43-0.92 \mathrm{~mm}^{-1 a y}{ }^{-1}$ for BY1 and $0.55-1.15 \mathrm{~mm}$ day $^{-1}$ for LJ43. The maximum adjusted $\mathrm{K}_{\mathrm{c}}$ values for both BY1 and LJ43 occurred in June 2020, while the minimum values appeared in June 2019 for BY1 and in June 2019 for LJ43. Overall, the monthly total $\mathrm{ET}_{0}$ during the experiment was $1034 \mathrm{~mm}$, and the $\mathrm{ET}_{\mathrm{C}}$ values for BY1 and LJ43 were $711 \mathrm{~mm}$ and $830 \mathrm{~mm}$, respectively. The average monthly adjusted $\mathrm{K}_{\mathrm{c}}$ values were 0.68 for BY1 and 0.82 for LJ43.

\section{Discussion}

In our study, the pattern of the cumulative rainfall-drainage curve fitted well with the linear plus platform model (Figure 3), indicating a critical amount rainfall that led to maximum drainage. This result may be attributed to the strong surface runoff in big rainfall events, because rainwater firstly arrives at the soil surface, and then runoff occurs if the soil surface has a slope. In addition, strong rainfall usually results in surface runoff happening faster than in rainwater infiltrate soils [35]. Previous research has proven that rainfall intensity and kinetic energy are key factors for determining the formation of runoff, and the rate of crust formation and groundwater infiltration [36-38]. Heavy rainfall intensity could shorten the formation time of runoff and sharply decrease the infiltrate curve $[39,40]$. However, previous studies also revealed that rainfall water prefers to infiltrate into the soil when the rainfall event is initiated, and finally forms the runoff when the soil water-adsorption capacity is saturated [41-43]. Thus, determining the saturation of soil water-adsorption capacity is vital for us to monitor the subsequent water movement in the field. In addition, an estimation of the runoff amount should be taken into account when applying the water balance equation to estimate drainage or evapotranspiration, which could improve the accuracy of estimating the drainage. Given that the runoff amount could not be estimated in our study, and considering that runoff only occurs in heavy rainfall situations, a linear plus platform model was applied to determine the relationship between 
cumulative rainfall and drainage, and the critical amount of rainfall was successfully estimated in our study. Consequently, we suggested that using the linear plus platform model to estimate the critical cumulative rainfall could be regarded as an alternative for this estimation, especially because runoff monitoring is absent in big rainfall events.

In the present study, the mean $\mathrm{K}_{\mathrm{c}}$ values of BY1 (0.71) and LJ43 (0.84) were slightly lower than the recommended value (0.9-1.0) for tea plants, according to the FAO Report [14], but were comparable to the mean value of 0.72 reported by Dabral for tea in Assam at different irrigation levels [44]. This result may be due to the young age of the tea plant, since plant growth stage is one of the most important factors for $\mathrm{K}_{\mathrm{c}}$ value, and lower $\mathrm{K}_{\mathrm{c}}$ values represent slower plant growth and lower canopy cover [45]. Similar results were found in citrus and grapevine orchard; for example, Alves et al. reported that the $\mathrm{K}_{\mathrm{c}}$ value of citrus orchard increased from 0.57 in a one-year-old plant to 1.12 in a four-year-old plant [46]. Similarly, the $\mathrm{K}_{\mathrm{c}}$ value of grapevine orchard increased from 0.4 (young shoot germination stage) to 1.0 (flourishing period) under freshwater irrigation [47].

As for the seasonal variation in $K_{c}$ values (Table 2), it seemed that a higher $K_{c}$ value often appeared during July to September, while lower values occurred during October to January. This phenomenon was in line with the trends of precipitation distribution and air temperature during the study period (Figures 1 and 2), suggesting that rainfall and air temperature could be responsible for the results. A previous study showed that the variation in $\mathrm{K}_{\mathrm{c}}$ values between seasons could be attributed to several reasons, such as the trend of canopy development, rainfall amounts in different seasons, and differences in energy absorption characteristics [4]. When plants received adequate water, together with increased temperature, this resulted in a rapid growth rate and peak of $\mathrm{ET}_{\mathrm{c}}$ and $\mathrm{K}_{\mathrm{c}}$ [4]. These findings were consistent with our results that the maximum $\mathrm{K}_{\mathrm{c}}$ value appears in July to November. In addition, a relatively lower $K_{c}$ value $($ mean $=0.71)$ was found in November to April; this may be due to the limited rainfall. This is because the limited rainfall caused soil moisture stress, and then resulted in declining growth rate, which, in turn, decreased the $\mathrm{ET}_{\mathrm{c}}$ and $\mathrm{K}_{\mathrm{c}}$ values. Moreover, Squire et al. reported that tea plant growth rate became very slow when the temperature was below $12-13{ }^{\circ} \mathrm{C}$ [48]. This is a good explanation of the higher $\mathrm{K}_{\mathrm{c}}$ in July to September and the lower $\mathrm{K}_{\mathrm{c}}$ values in October to January, because the mean temperature was $28.53{ }^{\circ} \mathrm{C}$ during July to August and $7.16^{\circ} \mathrm{C}$ during December to January.

During the experimental period, we found that heavy tea tree pruning decreased the $\mathrm{ET}_{\mathrm{c}}$ value and adjusted $\mathrm{K}_{\mathrm{c}}$ value of BY1 and LJ43 (Figures 4 and 5). This result was similar to the previous findings reported by Lv et al. [19], which were that the mean daily ET rates could decrease by $36.7-48.3 \%$ after pruning in a subtropical tea plantation, by using the static chamber/infrared gas analyzer (IRGA). Similarly, Geng et al. also found that strong pruning interference resulted in the highest differences between $\mathrm{ET}_{\mathrm{a}}$ and $\mathrm{ET}_{0}$ in the pruning period, compared to other seasons with relatively low mean monthly $\mathrm{ET}_{\mathrm{a}} / \mathrm{ET}_{0}$ values (average 0.76) [20]. The reason for this phenomenon may be related to the heavy pruning of tea resulting in a lower leaf area index (LAI), which, in turn, caused a decrease in the means of water transport, causing a decline in the $\mathrm{ET}_{\mathrm{c}}$ and $\mathrm{K}_{\mathrm{c}}$ values [20]. Moreover, from the dual crop coefficient perspective, Kato and Kamichika [49] found that the highly LAI-dependent basal crop coefficient $\left(\mathrm{K}_{\mathrm{cb}}\right)$, which represents crop transpiration, exponentially increased with the LAI, while the soil water evaporation coefficient $\left(\mathrm{K}_{\mathrm{e}}\right)$ showed a positive relationship with soil water content and a negative linear relationship with the LAI. Thus, intense tea pruning, on the one hand, lessened the LAI of tea bushes, which subsequently caused a reduction in the $\mathrm{K}_{\mathrm{cb}}$ value. On the other hand, a large quantity of pruned litter was discarded and covered in the tea garden's soil, which substantially curbed the soil water evaporation and the $K_{e}$ value. Therefore, we suggested that heavy tea pruning in May weakened the evapotranspiration capacity of the tea plantations.

Interestingly, our results found that the $\mathrm{ET}_{\mathrm{c}}$ value and $\mathrm{K}_{\mathrm{c}}$ value of BY1 were consistently lower than those of LJ43 (Table 2). This could be attributed to the differences in the plant growth status between BY1 and LJ43; the plant growth status can be easily reflected 
by the canopy structure, such as plant height, canopy width, leaf thickness, and LAI. The tea plant height, width, leaf thickness, and LAI of LJ43 were significantly greater than BY1 (Table 3). Therefore, LJ43 has a relatively well-structured canopy, which indicated that LJ43 had higher canopy cover and a greater LAI than BY1, resulting in higher values of $\mathrm{ET}_{\mathrm{C}}$ and $K_{c}$. These findings were in good agreement with the former study on pomegranate crops [14]. In addition, previous studies also revealed that the $\mathrm{K}_{\mathrm{c}}$ value has a strong relationship with LAI and soil coverage percentage in many fruit plantations, such as maize, bean, apple, and pecan [50-53]. Therefore, we suggested that the significantly higher LAI of LJ43, compared to BY1, could be another reason for the lower values of $\mathrm{ET}_{\mathrm{C}}$ and $\mathrm{K}_{\mathrm{c}}$ of BY1.

Table 3. Comparison of tea stands' properties between three different tea cultivars. Data are means and standard errors of 9 plots of tea stands. Different letters indicate significance $(p<0.05)$.

\begin{tabular}{ccccc}
\hline Tea Cultivars & Plant Height $(\mathbf{c m})$ & Plant Width $(\mathbf{c m})$ & Leaf Thickness $(\mathbf{c m})$ & LAI $\left.^{\left(\mathbf{m}^{2} \mathbf{~ m}\right.}{ }^{-\mathbf{2}}\right)$ \\
\hline DG & $94.53 \pm 1.22^{\mathrm{a}}$ & $111.58 \pm 1.43^{\mathrm{a}}$ & $41.22 \pm 0.63^{\mathrm{a}}$ & $8.65 \pm 0.13^{\mathrm{a}}$ \\
LJ43 & $88.83 \pm 1.01^{\mathrm{b}}$ & $110.14 \pm 1.23^{\mathrm{a}}$ & $39.94 \pm 0.48^{\mathrm{a}}$ & $8.72 \pm 0.17^{\mathrm{a}}$ \\
BY1 & $77.22 \pm 1.03^{\mathrm{c}}$ & $95.08 \pm 1.47^{\mathrm{b}}$ & $33.89 \pm 0.70^{\mathrm{b}}$ & $7.64 \pm 0.12^{\mathrm{b}}$ \\
\hline
\end{tabular}

Note: DG stands for Dangui, another tea cultivar besides BY1 and LJ43.

In our study, the experiment was conducted in a rain-fed subtropical region with uneven rainfall distribution during the study period. Therefore, the interval of drainage sampling from the lysimeter could not be scheduled uniformly, due to a lack of water input for certain periods, which occurred more often from November to January. Thus, the absence of data for the $\mathrm{ET}_{\mathrm{C}}$ and $\mathrm{K}_{\mathrm{c}}$ calculations during this period made it difficult to precisely reveal the monthly variation in water use status in the tea plantation, which needs to be further studied by alternative approaches for the monitoring and estimation of $\mathrm{ET}_{\mathrm{C}}$ and $\mathrm{K}_{\mathrm{c}}$. In addition, as RS- and GIS-based remote sensing approaches and algorithms have become important tools for $\mathrm{ET}_{\mathrm{c}}$ and $\mathrm{K}_{\mathrm{c}}$ estimation at a regional scale, we suggest that further studies should enhance the remote sensing measurements of the energy and water fluxes in tea plantations; for example, improving the monitoring accuracy via the integration of innovated methods to obtain the remote sensing data and meteorological variables, and subsequently using a readily available, open-source model (such as SEBALIGEE) to calibrate it with the ground-based lysimeter could produce larger spatiotemporal assessments.

\section{Conclusions}

In the present study, the linear plus platform model was applied to analyze the relationship between cumulative rainfall and lysimeter drainage, and critical cumulative rainfall values (78.02 $\mathrm{mm}$ for BY1 and $90.98 \mathrm{~mm}$ for LJ43) were obtained to estimate $\mathrm{ET}_{\mathrm{C}}$ and $K_{c}$ via the water balance equation when the cumulative rainfall was more than the critical value. Finally, $\mathrm{ET}_{\mathrm{c}}$ and adjusted $\mathrm{ET}_{\mathrm{c}}$, and the corresponding $\mathrm{K}_{\mathrm{c}}$ and adjusted $\mathrm{K}_{\mathrm{c}}$, were estimated by using the original cumulative rainfall. The $K_{c}$ values for BY1 and LJ43 ranged from 0.52 to 4.41 and from 0.55 to 4.39 , respectively, whereas the adjusted $\mathrm{K}_{\mathrm{c}}$ values of BY1 and LJ43 ranged from 0.43 to 1.02 and from 0.48 to 1.22 , respectively. The adjusted $\mathrm{ET}_{\mathrm{C}}$ and $\mathrm{K}_{\mathrm{c}}$ values revealed a minor fluctuation when compared to the $\mathrm{ET}_{\mathrm{C}}$ and $\mathrm{K}_{\mathrm{c}}$ values during the experimental period. In addition, periodic pruning significantly decreased the LAI of the tea plant, and resulted in a reduction in $\mathrm{ET}_{\mathrm{C}}$ and $\mathrm{K}_{\mathrm{c}}$ values. Furthermore, plant growth difference is a key factor contributing to the change in $\mathrm{ET}_{\mathrm{C}}$ and $\mathrm{K}_{\mathrm{c}}$ values between different tea cultivars. Collectively, our study provided a reliable reference of $K_{c}$ in a tea plantation, and illuminated the effects of pruning and plant growth difference on $\mathrm{K}_{\mathrm{c}}$.

Supplementary Materials: The following are available online at https: / / www.mdpi.com/article / 10.3390/agronomy11112332/s1, Figure S1: (a) Original images of BY1 and LJ43, (b) Illustration of experiment layout, lysimeter installation and soil volumetric water content probe site, and (c) Tea bushes on the study site, Figure S2: (a) Illustrations of lysimeter and leachate collecting from lysimeter, 
(b) Top view of lysimeter in-stalled, (c) Illustrations of the weather station and soil volumetric water content probe.

Author Contributions: Conceptualization, S.Z. and J.R.; writing-original draft preparation, S.Z.; writing-review and editing, K.N., L.J. and J.R.; formal analysis, C.Z. and H.C.; resources, X.Y. and W.H.; funding acquisition, J.R. All authors have read and agreed to the published version of the manuscript.

Funding: This work was financially supported by the Earmarked Fund for China Agriculture Research System (CARS 19); the Agricultural Science and Technology Innovation Program of the Chinese Academy of Agricultural Sciences (CAAS-ASTIP-2018-TRICAAS, CAAS-XTCX2016015).

Conflicts of Interest: The authors declare no conflict of interest.

\section{References}

1. Hasimoto, M. The origin of the tea plant. In Proceedings of the 2001 International Conference on O-CHA (Tea) Culture and Science, Shizuoka, Japan, 5-8 October 2001; Session I, pp. J5-J7.

2. Piyashee, M.; Tuhin, G. Impact of Climate on Tea Production: A Study of the Dooars Region in India. Res. Square 2021, 1-21. [CrossRef]

3. Chen, X.H.; Zhuang, C.G.; He, Y.F.; Wang, L.; Han, G.Q.; Chen, C. Photosynthesis, yield, and chemical composition of Tieguanyin tea plants (Camellia sinensis (L.) O. Kuntze) in response to irrigation treatments. Agric. Water Manag. 2010, 97, 419-425. [CrossRef]

4. Sikka, A.; Madegowda, M.; Sahoo, D.C. Determination of crop evapotranspiration of tea (Thea sinensis) using weighing lysimeter for the Nilgiris. J. Agrometeorol. 2009, 11, 144-147.

5. Ruiming, F.; Shijie, S. Daily reference evapotranspiration prediction of Tieguanyin tea plants based on mathematical morphology clustering and improved generalized regression neural network. Agric. Water Manag. 2020, 236, 106177. [CrossRef]

6. Ma, J.; Jia, X.; Zha, T.; Bourque, C.P.A.; Tian, Y.; Bai, Y.; Zhou, C. Ecosystem water use efficiency in a young plantation in Northern China and its relationship to drought. Agric. For. Meteorol. 2019, 275, 1-10. [CrossRef]

7. Ahmed, S.; Griffin, T.; Cash, S.B.; Han, W.Y.; Matyas, C.; Long, C.; Xue, D. Global Climate Change, Ecological Stress, and Tea Production. In Stress Physiology of Tea in the Face of Climate Change; Springer: Singapore, 2018; pp. 1-23. [CrossRef]

8. Ahmed, S.; Orians, C.M.; Griffin, T.S.; Buckley, S.; Unachukwu, U.; Stratton, A.E.; Kennelly, E.J. Effects of water availability and pest pressures on tea (Camellia sinensis) growth and functional quality. AoB Plants 2014, 6, plt054. [CrossRef]

9. Ahmed, S.; Stepp, J.R.; Orians, C.; Griffin, T.; Matyas, C.; Robbat, A.; Kennelly, E. Effects of Extreme Climate Events on Tea (Camellia sinensis) Functional Quality Validate Indigenous Farmer Knowledge and Sensory Preferences in Tropical China. PLoS ONE 2014, 9, e109126. [CrossRef] [PubMed]

10. Wijeratne, M.A. Vulnerability of Sri Lanka tea production to global climate change. Water Air Soil Pollut. 1996, 92, 87-94. [CrossRef]

11. Chen, B.; Yang, J.; Pu, J. Statistical Characteristics of Raindrop Size Distribution in the Meiyu Season Observed in Eastern China. J. Meteorol. Soc. Jpn. Ser. II 2013, 91, 215-227. [CrossRef]

12. Samuel, A.; Girma, A.; Zenebe, A.; Ghebreyohannes, T. Spatio-temporal variability of evapotranspiration and crop water requirement from space. J. Hydrol. 2018, 567, 732-742. [CrossRef]

13. Payero, J.O.; Irmak, S. Daily energy fluxes, evapotranspiration and crop coefficient of soybean. Agric. Water Manag. 2013, 129, 31-43. [CrossRef]

14. Allen, R.G.; Pereira, L.S.; Raes, D.; Smith, M. Crop Evapotranspiration-Guidelines for Computing Crop Water Requirements; FAO Irrigation and Drainage Paper 56; FAO: Rome, Italy, 1998; pp. 2-15.

15. Bhantana, P.; Lazarovitch, N. Evapotranspiration, crop coefficient and growth of two young pomegranate (Punica granatum L.) varieties under salt stress. Agric. Water Manag. 2010, 97, 715-722. [CrossRef]

16. Jiang, X.; Kang, S.; Tong, L.; Li, F.; Li, D.; Ding, R.; Qiu, R. Crop coefficient and evapotranspiration of grain maize modified by planting density in an arid region of northwest China. Agric. Water Manag. 2014, 142, 135-143. [CrossRef]

17. Kang, S.; Gu, B.; Du, T.; Zhang, J. Crop coefficient and ratio of transpiration to evapotranspiration of winter wheat and maize in a semi-humid region. Agric. Water Manag. 2003, 59, 239-254. [CrossRef]

18. Buttar, N.; Hu, Y.; Shabbir, A.; Lakhiar, I.; Ullah, I.; Ali, A. Estimation of Evapotranspiration Using Bowen Ratio Method. IFAC-PapersOnLine 2018, 51, 807-810. [CrossRef]

19. Lv, W.; Yang, G.; Wan, R. Daily variations of evapotranspiration rates of different ages tea plantation in Yixing city based on static chamber/igra. Res. Environ. Yangtze Basin 2012, 21, 1370. (In Chinese)

20. Geng, J.; Li, H.; Pang, J.; Zhang, W.; Chen, D. Dynamics and environmental controls of energy exchange and evapotranspiration in a hilly tea plantation, China. Agric. Water Manag. 2020, 241, 106364. [CrossRef]

21. Allen, R.G.; Masahiro, T.; Ricardo, T. Satellite-based energy balance for mapping evapotranspiration with internalized calibration (METRIC)-Model. J. Irrig. Drain. Eng. 2007, 133, 380-394. [CrossRef] 
22. Anderson, M.C.; Kustas, W.P.; Norman, J.M.; Hain, C.R.; Mecikalski, J.R.; Schultz, L.; González-Dugo, M.P.; Cammalleri, C.; d'Urso, G.; Pimstein, A.; et al. Mapping daily evapotranspiration at field to continental scales using geostationary and polar orbiting satellite imagery. Hydrol. Earth Syst. Sci. 2011, 15, 223-239. [CrossRef]

23. Allam, M.; Mhawej, M.; Meng, Q.; Faour, G.; Abunnasr, Y.; Fadel, A.; Xinli, H. Monthly 10-m evapotranspiration rates re trieved by SEBALI with Sentinel-2 and MODIS LST data. Agric. Water Manag. 2021, 243, 106432. [CrossRef]

24. Mhawej, M.; Nasrallah, A.; Abunnasr, Y.; Fadel, A.; Faour, G. Better irrigation management using the satellite-based adjusted single crop coefficient $\left(\mathrm{aK}_{\mathrm{c}}\right)$ for over sixty crop types in California, USA. Agric. Water Manag. 2021, 256, 107059. [CrossRef]

25. Dagg, M. A study of the water use of tea in East Africa using a hydraulic lysimeter. Agric. Meteorol. 1970, 7, 303-320. [CrossRef]

26. Sikka, K.; Sahoo, D.C.; Madhu, M.; Selvi, V. Determination of Crop Coefficient of Tea. J. Agric. Eng. 2009, 46, 41-45.

27. Lv, W.; Yang, G.; Wan, R.R.; Li, W.L. Comparative analysis of evapotranspiration rates of tea crops before and after pruning in the Western Hills of the Tai Lake Basin. Chin. J. Eco-Agric. 2013, 21, 184-191. [CrossRef]

28. Villoro, A.; Latorre, B.; Tormo, J.; José Jiménez, J.; Victoria López, M.; Manuel Nicolau, J.; Moret-Fernández, D. A TDR wireless device for volumetric water content sensing. Comput. Electron. Agric. 2021, 181, 105939. [CrossRef]

29. Page-Dumroese, D.S.; Brown, R.E.; Jurgensen, M.F.; Mroz, G.D. Comparison of Methods for Determining Bulk Densities of Rocky Forest Soils. Soil Sci. Soc. Am. J. 1999, 63, 379-383. [CrossRef]

30. Walinga, I.; Kithome, M.; Novozamsky, I.; Houba, V.J.G.; van der Lee, J.J. Spectrophotometric determination of organic carbon in soil. Commun. Soil Sci. Plant Anal. 1992, 23, 1935-1944. [CrossRef]

31. Sepaskhah, A.R.; Andam, M. Crop coefficient of sesame in a semi-arid region of I.R. Iran. Agric. Water Manag. 2001, 49, 51-63. [CrossRef]

32. Flumignan, D.L.; de Faria, R.T.; Prete, C.E.C. Evapotranspiration components and dual crop coefficients of coffee trees during crop production. Agric. Water Manag. 2011, 98, 791-800. [CrossRef]

33. Jensen, M.E.; Burman, R.D.; Allen, R.G. Evapotranspiration and Irrigation Water Requirements; ASCE Manuals and Reports on Engineering Practice No. 70; American Society of Civil Engineers: New York, NY, USA, 1990; p. 332.

34. Zotarelli, L.; Scholberg, J.M.; Dukes, M.D.; Muñoz-Carpena, R. Monitoring of Nitrate Leaching in Sandy Soils. J. Environ. Qual. 2007, 36, 953-962. [CrossRef] [PubMed]

35. Dexter, A.R. Advances in characterization of soil structure. Soil Tillage Res. 1988, 11, 199-238. [CrossRef]

36. Wang, H.; Gao, J.E.; Zhang, M.; Li, X.; Zhang, S.; Jia, L. Effects of rainfall intensity on groundwater recharge based on simulated rainfall experiments and a groundwater flow model. CATENA 2015, 127, 80-91. [CrossRef]

37. Liu, G.; Zheng, F.; Jia, L.; Jia, Y.; Zhang, X.; Hu, F.; Zhang, J. Interactive effects of raindrop impact and groundwater seepage on soil erosion. J. Hydrol. 2019, 578, 124066. [CrossRef]

38. Alizadehtazi, B.; Gurian, P.L.; Montalto, F.A. Impact of successive rainfall events on the dynamic relationship between vegetation canopies, infiltration, and recharge in engineered urban green infrastructure systems. Ecohydrology 2020, 13, e2185. [CrossRef]

39. Cuomo, S.; Della Sala, M. Rainfall-induced infiltration, runoff and failure in steep unsaturated shallow soil deposits. Eng. Geol. 2013, 162, 118-127. [CrossRef]

40. Assouline, S.; Ben-Hur, M. Effects of rainfall intensity and slope gradient on the dynamics of interrill erosion during soil surface sealing. CATENA 2006, 66, 211-220. [CrossRef]

41. Rao, K.P.; Steenhuis, T.; Cogle, A.; Srinivasan, S.; Yule, D.; Smith, G. Rainfall infiltration and runoff from an Alfisol in semi-arid tropical India. II. No-till systems. Soil Tillage Res. 1998, 48, 61-69. [CrossRef]

42. Wang, J.; Chen, L.; Yu, Z. Modeling rainfall infiltration on hillslopes using Flux-concentration relation and time compression approximation. J. Hydrol. 2018, 557, 243-253. [CrossRef]

43. Hueso-González, P.; Martínez-Murillo, J.F.; Ruiz-Sinoga, J.D. Benefits of adding forestry clearance residues for the soil and vegetation of a Mediterranean mountain forest. Sci. Total Environ. 2018, 615, 796-804. [CrossRef]

44. Dabral, P.P.; Rao, K.A. Estimation of crop coefficient and irrigation requirement under various irrigation levels for tea during dry period. Indian J. Soil Conserv. 1997, 25, 233-235.

45. Wang, T.; Melton, F.S.; Pôças, I.; Johnson, L.F.; Thao, T.; Post, K.; Cassel-Sharma, F. Evaluation of crop coefficient and evapotranspiration data for sugar beets from landsat surface reflectances using micrometeorological measurements and weighing lysimetry. Agric. Water Manag. 2021, 244, 106533. [CrossRef]

46. Alves, J., Jr.; Folegatti, M.V.; Parsons, L.R.; Bandaranayake, W.; da Silva, C.R.; da Silva, T.J.A.; Campeche, L.F.S.M. Determination of the crop coefficient for grafted 'Tahiti' lime trees and soil evaporation coefficient of rhodic kandiudalf clay soil in Sao Paulo, Brazil. Irrig. Sci. 2007, 25, 419-428. [CrossRef]

47. Netzer, Y.; Yao, C.; Shenker, M.; Bravdo, B.A.; Schwartz, A. Water use and the development of seasonal crop coefficients for Superior Seedless grapevines trained to an open-gable trellis system. Irrig. Sci. 2009, 27, 109-120. [CrossRef]

48. Squire, G.R. Weather, physiology and seasonality of tea (Camellia sinensis L.) yields of Malawi. Exp. Agric. 1979, 15, 321-330. [CrossRef]

49. Kato, T.; Kamichika, M. Determination of a crop coefficient for evapotranspiration in a sparse sorghum field. Irrig. Drain. 2006, 55, 165-175. [CrossRef]

50. Shao, G.; Han, W.; Zhang, H.; Liu, S.; Wang, Y.; Zhang, L.; Cui, X. Mapping maize crop coefficient $\mathrm{K}_{\mathrm{c}}$ using random forest algorithm based on leaf area index and UAV-based multispectral vegetation indices. Agric. Water Manag. 2021, 252, 106906. [CrossRef] 
51. De Medeiros, G.A.; Arruda, F.B.; Sakai, E.; Fujiwara, M. The influence of crop canopy on evapotranspiration and crop coefficient of bean (Phaseolus vulgaris L.). Agric. Water Manag. 2001, 49, 211-224. [CrossRef]

52. Gong, D.; Kang, S.; Yao, L.; Zhang, L. Estimation of evapotranspiration and its components from an apple orchard in northwest China using sap flow and water balance methods. Hydrol. Process. 2007, 21, 931-938. [CrossRef]

53. Wang, J.; Sammis, T.W.; Andales, A.A.; Simmons, L.J.; Gutschick, V.P.; Miller, D.R. Crop coefficient of open-canopy pecan orchards. Agric. Water Manag. 2007, 88, 253-262. [CrossRef] 